\title{
Przygotowanie i ocenianie zadań kształcących kreatywność i myślenie projektowe uczniów
}

DOI: $10.47050 / 65591876.66-78$

Adam Kalbarczyk

Celem rozdziału jest przedstawienie typologii zadań kształcących kreatywność u uczniów oraz kryteriów ich oceniania. Założenia teoretyczne wykorzystane w pracy obejmują następujące twierdzenia:

$\rightarrow$ Kształcenie kreatywności jest ważnym zadaniem współczesnej edukacji szkolnej i powinno obejmować wszystkich uczniów.

$\rightarrow$ Zadania kształcące kreatywność powinny być grupowymi zadaniami projektowymi.

$\rightarrow$ Tematy zadań powinny być atrakcyjne dla uczniów.

Przedstawiona w rozdziale propozycja typów zadań odwołuje się do naturalnych dla ludzi procesów wprowadzania oryginalnych i twórczych nowości do systemu językowego (derywacje, neologizmy, zapożyczenia, metafory, kompozycje, inwencje słowne). Trzy proponowane kryteria oceny tego rodzaju zadań obejmują: oryginalność, trafność i elegancję rozwiązań.

\section{Słowa kluczowe:}

kreatywność

ćwiczenie twórczości / trening twórczości

myślenie projektowe / Design thinking

praca grupowa

umysł zbiorowy

zadanie dla uczniów

kryteria oceny 


\section{Preparation and assessment of tasks that form students creativity and design thinking}

DOI: 10.47050/65591876.66-78

Adam Kalbarczyk

The aim of this chapter is to present a typology of students tasks that form creativity and to list criteria of their assessment. The work is based on theoretical assumptions listed below:

$\rightarrow$ Creativity forming is an important aim of contemporary school education and should embrace all students.

$\rightarrow$ Tasks that form creativity should be group project tasks.

$\rightarrow$ The topic of the tasks should be attractive for students.

The proposal included in this work connects with natural human processes of introducing new and original solutions to the language system (derivations, neologisms, loan-words, metaphors, compositions, word inventions).

Three proposed criteria of assessment of creativity tasks embrace: originality, accuracy and elegance of solutions.

Keywords:

creativity

creativity exercising / creativity training

project thinking / Design thinking

group work

common mind

students task

assessment criteria 


\section{Wprowadzenie}

Niniejszy rozdział przedstawia typy zadań możliwych do wykorzystania w praktyce szkolnej w celu kształcenia kreatywności u uczniów oraz propozycje kryteriów ich oceny. U podstaw tego opracowania leży przekonanie, że kreatywność warto i można kształcić w szkole. Warto, dlatego że przez bardzo wielu współczesnych ekspertów edukacyjnych zaliczana jest ona do kluczowych "kompetencji przyszłości” (Robinson 2016; Zhao 2012). Wymienia się ją także wśród kompetencji kluczowych w Zaleceniu Rady Unii Europejskiej z dnia 22 maja 2018 r. w sprawie kompetencji kluczowych w procesie uczenia się przez całe życie. Rada UE zaleca tam m.in. „pielęgnowanie kompetencji w zakresie przedsiębiorczości, kreatywności i zmysłu inicjatywy, szczególnie wśród młodych ludzi" (Zalecenie Rady UE 2018). Można zaś ją rozwijać i pielęgnować zgodnie z przekonaniem, że ludzkie zdolności twórcze nie dotyczą tylko wybranych, wybitnych jednostek, ale mają charakter powszechny i mogą być kształcone u każdej osoby.

Kształcenie kreatywności w szkole stało się jej niedyskutowanym zadaniem od czasu, gdy do powszechnej świadomości dotarło przekonanie, że tradycyjny model edukacji nie tylko nie służy rozwijaniu kreatywności u uczniów, ale także wpływa na obniżenie twórczego potencjału dzieci. Najbardziej znanym raportem w tym zakresie było opracowanie Kena Robinsona, którego badania z lat 80. ubiegłego wieku wywołały wstrząs w Wielkiej Brytanii (Robinson 1982). W wielu swoich pracach badacz ten przekonuje dziś nie tylko o wartości, ale także o niezbędnej potrzebie kształcenia kreatywności w szkołach (Robinson 2010, 2016).

Podobnie jest również po drugiej stronie oceanu. Jeden z najbardziej wpływowych amerykańskich ekspertów edukacyjnych Yong Zhao mówi o konieczności przygotowania uczniów do pełnienia roli samodzielnych przedsiębiorców, umiejących twórczo rozwiązywać problemy, w odróżnieniu od dotychczasowej praktyki kształcenia pracowników potrafiących przede wszystkim doskonale wykonywać zadania odtwórcze (Kalbarczyk 2015; Richardson i in. 2017; Zhao 2012).

\section{Przesłanki kształcenia kreatywności}

Według Edwarda Nęcki istnieją trzy przesłanki, by twierdzić, że twórczość można ćwiczyć (trenować). Są nimi: humanistyczna wizja człowieka, postrzeganego jako podmiot twórczy; dostrzeganie przejawów 
twórczości „potencjalnej” w zwyczajnych działaniach ludzi (zwłaszcza dzieci) oraz zwyczajność operacji intelektualnych składających się na akty twórcze (Nęcka i in. 2012, s. 10).

Kreatywność jest w psychologii rozumiana jako właściwość ludzi, procesów i produktów (Nęcka 2003, s. 13). Wśród licznych definicji tej cechy badacze wskazują na powtarzalność jej dwu elementów konstytutywnych: nowości i wartościowości. Kreatywni ludzie zatem to ci, którzy są zdolni do wytwarzania nowych i wartościowych produktów, rozumianych szeroko, nie tylko w sensie materialnym (Nęcka 2003, s. 13, 19; Szmidt 2007, s. 53). Procesy twórcze to zaś takie procesy psychiczne, które prowadzą do wytworzenia nowych i wartościowych idei, produktów w szerokim sensie (Nęcka 2003, s. 35). Celem kształcenia kreatywności w szkole byłoby więc kształcenie zdolności u uczniów do wytwarzania nowych i wartościowych produktów. Zdolności te według Zhao składają się z trzech elementów: 1) zdolności poznawczych, pozwalających na odkrywcze powiązanie istniejących zjawisk i przedmiotów oraz tworzenie z nich nowych rezultatów/produktów; 2) odwagi tworzenia, łączącej postawę otwartości umysłowej z gotowością pokonywania wyzwań, trudności i niepewności-emocjonalnego ryzyka w celu odkrywania nowych rozwiązań; 3) nastawienia na społeczną wartość podejmowanych działań (Richardson i in. 2017).

Jeżeli kreatywność jest pewnym rodzajem ludzkich zdolności, które ujawniają się w procesach prowadzących do tworzenia nowych i wartościowych produktów, to - jak każda zdolność - podlega ona kształceniu. Jego podstawą jest działanie. Referując raport Robinsona (Robinson 1999), Krzysztof Szmidt pisał: „Twórczość ma swoje źródło w wielu zwyczajnych zdolnościach i umiejętnościach, a nie w odosobnionym talencie. $Z$ tego względu w rozwijaniu twórczości pomocne jest pobudzanie i wspieranie prostych uzdolnień wrażliwości i sprawności. [...] zdolności twórcze są najlepiej wspierane w procesie stawania się twórczym. Dlatego właśnie uczenie się przez działanie może być podstawą nauczania twórczości, a przebiega ono najlepiej i może być właściwie wzbogacane dzięki pracy pod kierunkiem mentorów i mistrzów" (Szmidt 2007, s. 22).

\section{Techniki i metody ksztalcenia kreatywności}

Badacze kreatywności opisują różne techniki, metody i strategie kształcenia kreatywności. Edward Nęcka proponuje metodę twór- 
czego rozwiązywania problemów, która składa się z działań w dwu przestrzeniach: problemu i rozwiązań. Każdy z nich dzieli się na trzy fazy postępowania z problemem i jego rozwiązaniem (Nęcka 1994). Witold Dobrołowicz opisuje cztery rodzaje treningu twórczości: instrumentalny, stosowania metod inwentycznych, osobowościowy i abarietyczny, czyli służący przełamywaniu barier psychologicznych (Szmidt 2005, s. 58-66). Ellis P. Torrance wyróżnia sześć typów tego treningu, w tym trening ćwiczący umiejętność rozwiązywania problemów i rozwijający twórcze pisanie. Jane Piirto wymienia kilkanaście technik treningu twórczości, m.in. trening twórczego rozwiązywania problemów. Opis tych treningów można znaleźć w opracowaniu Krzysztofa Szmidta (Szmidt 2007, s. 299-300). Cechą wspólną tych ujęć są zadania kształcące twórcze rozwiązywanie problemów. Zadania kształcące kreatywność są więc elementem wielu (jeśli nie wszystkich) programów "wychowania do twórczości". Ich przegląd można znaleźć także u Szmidta (Szmidt 2007, s. 308 i n.). Są to m.in.: CoRT (Cognitive Research Trust) Edwarda de Bono, Future Problem Solving Ellisa P. Torrance'a i Pansy Torrance, Creative Problem Solving Scotta Isaksena, Donalda Treffingera i Briana Dorvala czy CIFS (Creative Intelligence for School) Roberta Sternberga.

Problemy (zadania) służące najskuteczniejszemu kształceniu kreatywności według Torrance'a, zastosowane w programie realizującym zasady jego Inkubacyjnego Modelu Nauczania, to zadania, w których znalezienie najlepszych rozwiązań jest poprzedzone ustaleniem kryteriów sukcesu tych rozwiązań, podjęciem decyzji co do ich wyboru oraz których rozwiązanie obejmuje proces ulepszania i ewaluacji oraz praktycznego zastosowania, czyli wdrożenia innowacji (Szmidt 2007, s. 313). Innowacja jest tu rozumiana jako „proces wdrażania, zastosowania, przyswojenia nowości" czy też, jak ujmuje to Michael A. West, "przekładania nowych idei na język praktyczny” (Szmidt 2007, s. 54, 56).

Wskazuje to bardzo wyraźnie na związek tego typu zadań z myśleniem projektowym. Jedną z najbardziej znanych metod tworzenia nowych produktów i wdrażania innowacji jest metoda Design thinking opracowana przez Tima Browna. Polega ona na tworzeniu nowych, oryginalnych produktów, procesów lub rozwiązywaniu problemów, ale przez osoby, jak podkreśla twórca tej metody, niezwiązane profesjonalnie z projektowaniem i zastosowanie jej do szerszego zakresu rozwiązań niż tylko projektowanie w sensie ścisłym (Helman, Rosienkiewicz 2016). 


\section{Zasady myślenia projektowego}

Projektowanie według założeń tej metody: 1) jest czynnością społeczną; 2) wymaga eksperymentowania i uwzględnienia różnych punktów widzenia; 3) jest zwykle „przeprojektowywaniem" rozwiązań, które już istnieją; 4) wymaga wizualizacji i tworzenia prototypów (Helman, Rosienkiewicz 2016). Metoda ta stanowi zatem doskonałe źródło tworzenia zadań kształcących kreatywność uczniów. Jej zastosowanie daje możliwość kompleksowego kształcenia uczniowskiej kreatywności i wykorzystywania jej w życiu. W odróżnieniu od ćwiczeń rozwijających jakiś aspekt lub element kreatywności zadanie projektowe daje możliwość wieloaspektowego i wszechstronnego kształcenia kreatywności u uczniów.

Zgodnie z zasadami myślenia projektowego zadanie kształcące kreatywność u uczniów powinno cechować się następującymi właściwościami: 1) jego celem powinno być stworzenie nowego, wartościowego produktu; 2) powinno być zadaniem grupowym; 3) powinno pozwalać na aktywne poszukiwanie rozwiązań i eksperymentowanie z nimi; 4) powinno odwoływać się do wiedzy o istniejących rozwiązaniach; 5) powinno pozwalać na przetestowanie rozwiązań i ich ewaluację; 6) powinno być wykonywane metodycznie, zgodnie z określoną dla projektowania procedurą. Procedura ta obejmuje, tak jak w profesjonalnym projektowaniu, pięć etapów (Helman, Rosienkiewicz 2016):

$\rightarrow$ empatyzację,

$\rightarrow$ definiowanie problemu,

$\rightarrow$ generowanie pomysłów

$\rightarrow$ budowanie prototypów,

$\rightarrow$ testowanie.

Wszystkie te etapy powinny być uwzględnione podczas wykonywania zadań projektowych przez uczniów.

\section{Forma grupowa w ksztalceniu kreatywności}

Zastosowanie formy grupowej do kształcenia kreatywności może na pierwszy rzut oka budzić wątpliwości. Największe dzieła artystyczne w historii ludzkości powstały przecież jako dzieła jednostek, a nie grup. Należy jednak zwrócić uwagę, że jednostki te nie potrzebowały żadnego kształcenia kreatywności i wykorzystały swój naturalny potencjał, który w wielu przypadkach służył także zbiorowości i był wykorzysty- 
wany później w działaniach grupowych. Z kolei stopień skomplikowania zadań, które stoją współcześnie przed ludzkością, wymaga pracy zespołowej i zbiorowego rozwiązywania problemów. Tak pracują dziś zespoły badawcze i twórcy nowych rozwiązań technologicznych. Co wciąż nie wyklucza działań tych wybitnych jednostek, które, zwłaszcza w dziedzinie sztuki, żadnego ćwiczenia kreatywności nie potrzebują.

O zaletach pracy grupowej w kształceniu kreatywności pisze m.in. Edward Nęcka. Opisując właściwości "umysłu zbiorowego", wskazuje na obserwowany przez wielu badaczy, występujący w przypadku zbiorowego działania twórczego, efekt synergii, w wyniku którego giętkość myślenia zbiorowego nie jest prostym zwielokrotnieniem zdolności twórczych członków grupy, a jego produktywność nie jest prostą sumą pomysłów każdego z jej członków (Góralski 1996, s. 16; Nęcka 1994, s. 83). Pisząc o szansach myślenia grupowego, wymienia Nęcka przewagi, jakie daje nad kreatywnością indywidualną różnorodność członków grupy, organizacja jej działań, tzw. efekt publiczności i wolny rynek idei (Nęcka 1994, s. 78-82). Nęcka opisuje także zagrożenia myślenia grupowego (Nęcka 1994, s. 74-78). Niektóre z nich nie dotyczą jednak uczniów (brak zagrożenia presji autorytetów, brak przywiązania uczniów do własności pomysłów czy małe ryzyko wystąpienia syndromu „ogłupienia grupowego", ponieważ uczniowie nie są ekspertami i nie działają pod nadmierną presją czasu). Oczywiście w pracy w grupie zawsze może wystąpić napięcie emocjonalne między członkami zespołu czy konflikt związany z ich zróżnicowaniem, a także zachowania autocentryczne. Nęcka zwraca zarazem uwagę, że kreatywne działania zespołowe powinny odbywać się w odpowiednich warunkach, które obejmują wzajemną sympatię członków grupy, ich zaciekawienie zadaniem, ludyczny nastrój jego wykonania, a także poczucie bezpieczeństwa i wolności (Nęcka 1994, s. 84).

Najbardziej wszechstronne zadania kształcące kreatywność wśród uczniów to zatem grupowe zadania projektowe. Warto zarazem zwrócić uwagę na autentyczność, praktyczność ich przedmiotu. Zadania budzące ciekawość, atrakcyjne dla uczniów nie powinny mieć charakteru problemów sztucznych, stworzonych tylko na użytek szkolny (Szmidt 2005, s. 96). Opisując zadania, które służą rozwojowi zdolności twórczych u uczniów, Szmidt wymienia cztery warunki, które zadania te powinny spełniać. Powinny one być: 1) otwarte, wzbudzające ciekawość uczniów, zachęcające do tworzenia wielu pomysłów na ich rozwiązanie; 2) różnorodne, angażujące "całą postawę twórczą" uczniów; 3) 
sprzyjające opanowaniu reguł użytecznych w rozwiązywaniu problemów; 4) autentyczne, związane z codziennym życiem uczniów i ich środowiskiem (Szmidt 2005, s. 97). Warto dodać, że jeżeli zadanie nie ma charakteru "życiowego", to może być atrakcyjne dla uczniów także wówczas, gdy będzie miało charakter zabawowy, ludyczny.

\section{Typy zadań ksztalcących kreatywność uczniów}

W klasyfikacji zadań kształcących kreatywność uczniów proponuję uwzględnić typy produktów będących ich celem i w związku z tym do jej przeprowadzenia zastosować podział procesów wykorzystywanych przez ludzi w działaniach słowotwórczych i semantycznych. Podobnie jak język stale rozwija się wskutek wykorzystania swych możliwości systemowych poprzez tworzenie nowych tworów słownych lub znaczeniowych, tak też zachodzą procesy twórcze. Przebiegają one w sposób podobny do działań w ramach systemu językowego, czyli analogicznie do tworzenia innowacji językowych - leksykalnych i semantycznych. Typy procesów twórczych, którym odpowiadają określone rodzaje zadań kształcących kreatywność u uczniów, obejmowałyby zatem:

$\rightarrow$ konstrukcję systemową (odpowiednik derywacji słowotwórczej - stworzenie nowego wyrazu z istniejącego lub istniejących wyrazów w ramach możliwości danego systemu),

$\rightarrow$ zapożyczenie (adaptacja wyrazu $z$ innego systemu językowego na zasadzie analogii znaczeń),

$\rightarrow$ przeniesienie znaczeń (neosemantyzacja, metafora),

$\rightarrow$ złożenia (kompozycje, połączenia dotychczas istniejących elementów),

$\rightarrow$ wynalazki (odpowiednik innowacyjnego neologizmu pozasystemowego).

Przykładami zadań dla każdego z procesów byłyby:

$\rightarrow$ uczniowski wytwór z istniejących utworów (np. oryginalne uczniowskie przedstawienie teatralne stworzone na podstawie istniejących tekstów, rozwiązanie zadania matematycznego w nowy oryginalny sposób, samodzielne przeprowadzenie eksperymentu przyrodniczego przez uczniów),

$\rightarrow$ stworzenie produktu analogicznego (np. stworzenie oryginalnego, uczniowskiego języka obrazkowego do opisu fragmentu rzeczywistości), 
$\rightarrow$ wykorzystanie istniejących rozwiązań/produktów do nowych celów (np. uczniowski projekt recyclingowy),

$\rightarrow$ innowacyjne połączenie istniejących elementów (np. autorskie zilustrowanie istniejącego tekstu istniejącym utworem muzycznym; autorska wystawa plastyczna),

$\rightarrow$ nowy oryginalny utwór uczniowski (np. autorski tekst, wiersz, plakat, film, spektakl).

Przykładem zadania 1), które polegałoby na twórczym wykorzystaniu istniejących elementów, byłoby zadanie wykorzystywane przeze mnie w praktyce szkolnej nauczania filozofii w liceum:

$\rightarrow$ Cel projektu: wystawienie minispektaklu filozoficznego, w którym głównymi bohaterami będą filozofowie toczący ze sobą spór (rozmowę) na wybrany (poniżej) temat.

$\rightarrow$ Czas trwania spektaklu: maksymalnie 10 minut.

$\rightarrow$ Zespół projektowy: 4-5 uczniów, z których każdy odgrywa w spektaklu rolę któregoś z filozofów.

$\rightarrow$ Tematy i bohaterowie przedstawień (wybrani filozofowie mogą być zastąpieni przez innych, a nawet przez postacie fikcyjne):

- Czy świat istnieje? Osoby: Platon (Państwo - alegoria jaskini), Kartezjusz (Medytacje o pierwszej filozofii), David Hume (Traktat o naturze ludzkiej), George Berkeley (Traktat o zasadach ludzkiego poznania), Tadeusz Kotarbiński (O postawie reistycznej, czyli konkretystycznej).

- Czy można być czegokolwiek pewnym? Osoby: Sekstus Empiryk (Zarysy pyrrońskie), Platon (Fedon), Kartezjusz (Medytacje o pierwszej filozofii), Immanuel Kant (Prolegomena do wszelkiej przyszłej metafizyki), Kazimierz Ajdukiewicz (konwencjonalizm poznawczy).

- Czy Bóg istnieje? Osoby: Anzelm z Canterbury (tzw. ontologiczny dowód na istnienie Boga), Tomasz z Akwinu (Summa teologiczna - tzw. pięć dróg - "dowodów" na istnienie Boga), Kartezjusz (Medytacje o pierwszej filozofii), Jean-Paul Sartre (Egzystencjalizm jest humanizmem), Sam Harris (Koniec wiary).

- Jak dobrze postępować? Osoby: Sokrates (Platon, Obrona Sokratesa), Arystoteles (Etyka nikomachejska), Augustyn Aureliusz (Wyznania), John Stuart Mill (Utylitaryzm), Peter Singer (Jeden świat. Etyka globalizacji). 
$\rightarrow$ Etapy zadania do wykonania:

- znalezienie tekstów filozoficznych (literackich) dotyczących określonej tematyki,

- wybór fragmentów odpowiadających tematyce,

- skonstruowanie scenariusza spektaklu z fragmentów wybranych tekstów; uwaga: całość nie może przekraczać 2 stron maszynopisu (czcionka Times New Roman 12, interlinia 1,5),

- opracowanie inscenizacji (ruch sceniczny, rekwizyty, kostiumy, ewentualnie: muzyka, światła, wykorzystanie multimediów itp.),

- podział ról (jeden uczeń - jeden filozof),

- przeprowadzenie prób spektaklu,

- nauczenie się ról,

- zaprezentowanie spektaklu.

Tekstów szukajcie w: B. Markiewicz, Filozofia dla szkoły średniej, w książkach podanych filozofów lub w internecie.

Przykładem zadania 2), polegającego na stworzeniu produktu analogicznego, może być zadanie zamieszczone w podręczniku do języka polskiego dla liceów i techników Oblicza epok (2019):

W kilkuosobowych grupach opracujcie projekt pisma obrazkowego, którego elementy posłużą do przełożenia poezji na mowę zrozumiałą dla dzieci dopiero rozpoczynających naukę czytania i pisania w języku polskim (np. uczniów pierwszej klasy szkoły podstawowej). Opracujcie ogólne założenia pisma, formę graficzną znaków - możecie się inspirować różnymi pismami obrazkowymi, hieroglifami egipskimi, pismem Majów, techniką rebusów itp. Następnie przygotujcie przekład fragmentu Ogrodu przedziwnego Leopolda Staffa:

W przedziwnym mieszkam ogrodzie,

Gdzie żyją kwiaty i dzieci

I gdzie po słońca zachodzie

Uśmiech nam z oczu świeci.

Wodotrysk bije tu dziwny,

Co śpiewa jak śmiech i łkanie;

Krzew nad nim rośnie oliwny

Cichy jak pojednanie. [...] 
Postępujcie zgodnie z podaną kolejnością działań, by skutecznie zrealizować swój projekt:

$\rightarrow$ Analiza założeń i danych: ustalenie, na czym ma polegać przekład wiersza, do kogo ma być adresowany, jakie cechy sprawią, że będzie zrozumiały dla odbiorców (dzieci) oraz analiza i interpretacja fragmentu w celu zrozumienia jego sensów.

$\rightarrow$ Analiza problemu: zdobycie informacji na temat pisma obrazkowego (czym się charakteryzuje, z czego się składa, jakie warunki musi spełniać) oraz poznanie istniejących systemów takiego pisma.

$\rightarrow$ Opracowanie koncepcji: zebranie pomysłów i stworzenie założeń projektowanego pisma (z jakich elementów powinno się składać, jak mają wyglądać znaki, czy będą proste i złożone, jakie będą zasady ich tworzenia, jak zapewnić pismu spójność i możliwość tworzenia nowych znaków itp.).

$\rightarrow$ Stworzenie prototypu pisma: opracowanie modelowych znaków spełniających założenia przyjęte w koncepcji.

$\rightarrow$ Przetestowanie prototypu: przełożenie fragmentu wiersza Staffa przy użyciu opracowanego pisma obrazkowego i sprawdzenie, czy dzieci rozumieją przekład.

$\rightarrow$ Stworzenie (opisanie) zasad pisma po wyciągnięciu wniosków z testów.

\section{ETAPY PRZYGOTOWANIA PROJEKTU}

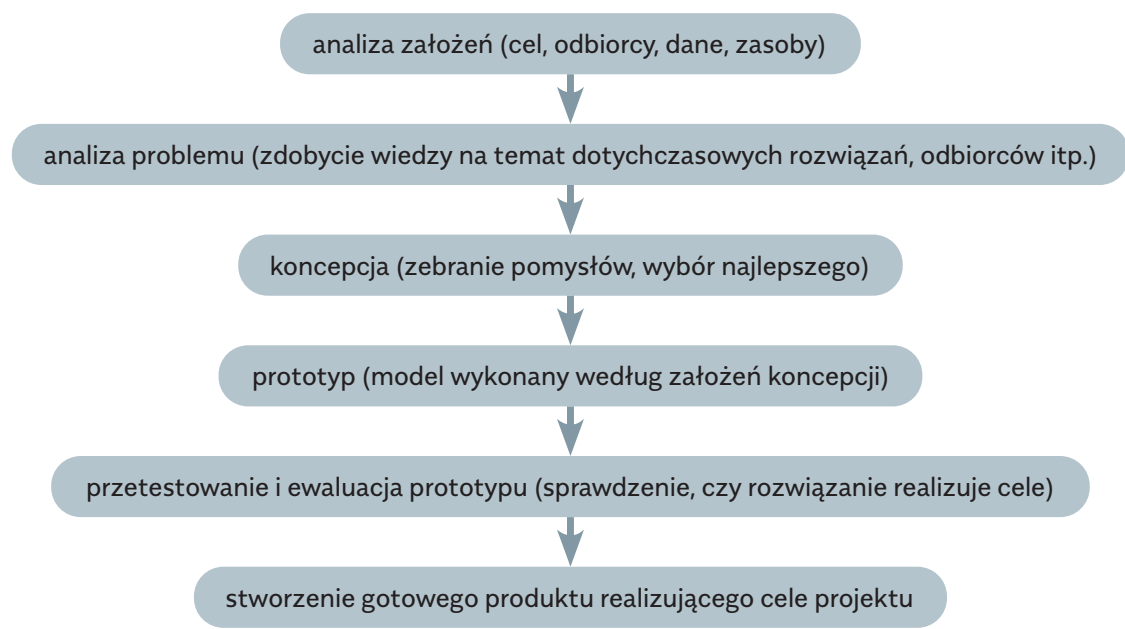


Przykładem zadania 3) byłoby zadanie techniczne, w ramach którego uczniowie mieliby zbudować jakiś nowy produkt z używanych elementów, np. tablicę z oznaczeniem swojej sali lekcyjnej z plastikowych i metalowych odpadków, albo zadanie gastronomiczne, np. polegające na przygotowaniu potrawy z tego, co aktualnie znajduje się w lodówce szkolnej pracowni.

Przykładem zadania 4) byłoby zadanie projektowe zamieszczone w cytowanym wyżej podręczniku do języka polskiego:

Przygotujcie wystawę Ludzie i bogowie w mitologii greckiej poświęconą konfliktom między bogami a ludźmi. Wykorzystajcie dzieła plastyczne, muzyczne, teatralne i filmowe.

\section{Ocenianie zadań kształcących kreatywność uczniów}

Ewaluacja tego rodzaju zadań powinna koncentrować się na ocenie jakości obiektywnych produktu, a nie (zgodnie z klasyfikacją Nęcki) - na kryteriach subiektywno-emocjonalnych i samym procesie twórczym (Nęcka 2003, s. 32-33). Kryteriami oceny powinny zatem być - zgodna ze skalą semantyczną dzieł twórczych Susan Besemer i Karen O'Quinn (Nęcka 2003, s. 29) oraz odpowiednia dla przyjętej wyżej definicji twórczego produktu:

$\rightarrow$ jakość rozwiązania - oryginalność, innowacyjność, nowość;

$\rightarrow$ celowość wykonania - trafność, użyteczność, adekwatność;

$\rightarrow$ styl rezultatu - elegancja, staranność wykonania (dotyczy głównie indywidualnych twórczych zadań typu 5, polegających na tworzeniu np. autorskiego tekstu przez uczniów).

\section{Podsumowanie}

W niniejszym rozdziale przedstawiono opis typów zadań kształcących kreatywność uczniów oraz propozycję ich oceny. Typologia zadań kształcących zdolności twórcze uczniów obejmuje pięć rodzajów tych zadań i została zbudowana analogicznie do klasyfikacji działań słowotwórczych i semantycznych, służących ludziom do tworzenia nowych słów, wyrażeń i konstrukcji znaczeniowych. Propozycja kryteriów oceny zadań kształcących zdolności twórcze obejmuje trzy obszary, zgodne z definicją kreatywnego produktu. Opis tych zadań i kryteriów ich oceny został poprzedzony przedstawieniem założeń, które pozwalają mówić zarówno o zadaniach kształcących kreatywność uczniów, jak 
i o ich ocenie. Założeniami tymi są: przekonanie o wartości i konieczności kształcenia kreatywności w szkole (rozumianej jako zdolność uczniów do tworzenia produktów nowych i wartościowych społecznie) oraz uznanie możliwości takiego kształcenia, obejmującego wszystkich uczniów, czego dowodzą liczne istniejące i opisane techniki i metody ćwiczenia kreatywności. Podstawowym założeniem dotyczącym formy wykonania zadań jest przekonanie o wartości pracy grupowej w kształceniu kreatywności oraz uznanie myślenia projektowego za wzór modelu działania twórczego. 